\title{
がん化学療法による好中球減少症の リスクファクターに関する研究
}

\author{
矢野良一 ${ }^{*}$ \\ 福井大学医学部附属病院薬剤部
}

\section{Risk Factors of Severe Neutropenia during Cancer Chemotherapy}

\author{
Ryoichi Yano* \\ Department of Pharmacy, University of Fukui Hospital \\ $\left[\begin{array}{l}\text { Received November 11, } 2013 \\ \text { Accepted April 2, 2014 }\end{array}\right]$
}

Because neutropenia involves susceptibility to severe infection, appropriate management of neutropenia is required during cancer chemotherapy. Assessing individual patients' background to identify those at high risk is an important step. A systematic review of the literature was performed to overview recent findings about neutropenia risk factors. Type of cancer, treatment regimen, patient age, gender, performance status, comorbidities, laboratory abnormalities, prior therapies and some genetic polymorphisms were reported as risk factors for neutropenic complications.

We have reported novel findings on the risk factor of severe neutropenia by using a pharmacoepidemiologic approach. One of them clarifies the increased risk by drug-drug interaction between vinorelbine and clarithromycin. Patients who were administered clarithromycin during chemotherapy with vinorelbine were at 4.52-times higher risk for severe neutropenia compared with patients who were administered vinorelbine alone. Another study reveals ethnic diversity in docetaxel toxicity between Asian and non-Asian clinical studies using integrated analysis of published articles. Clinical trials conducted in Asia had 19.0 times higher risk on severe neutropenia compared with non-Asian trials. Pharmacists and clinicians should mention such ethnic diversity.

Like our studies, a pharmacoepidemiologic approach is useful for the clinical pharmacists' study that aims to identify risk factors on pharmacotherapy.

Key words — cancer chemotherapy, neutropenia, risk factors, drug-drug interaction, pharmacoethnicity, pharmacoepidemiology

\section{はじめに}

がん化学療法において，好中球減少症は発現頻 度が高い副作用である．末梢血中の好中球数の減 少は感染症の発症率と密接に関連しており, ${ }^{1)}$ 重 篤な好中球減少症は敗血症, 深部臓器の感染症な ど致死的な感染症のリスクと関連するため多くの 薬剤の用量規制因子となっている，好中球減少症 は投与量の減少, 治療の延期や中止など治療強度 の低下に直結する。従って治療開始前に重篤な好 中球減少症の発現リスクを評価し, 適切なモニ夕 リングと対処により重篤化を回避することは, 感
染症による生命危機の回避に寄与するばかりでな く, 治療計画の遵守につながり, 結果的に患者に とって最良のアウトカム達成に貢献することが期 待される.

著者らはこれまでに，がん化学療法による好中 球減少症のリスクファクターに関する検討や適切 なモニタリング方法に関する検討を進めてきた。 そのうち, 好中球減少症の適切なモニタリング方 法に関する検討では，がん化学療法を施行された 患者に打ける末梢血中の白血球数と好中球分画の 関係について検討を行い, 白血球数の減少に伴っ て好中球分画の割合も低下すること, 安易に白血

\footnotetext{
* ₹910-1193 福井県吉田郡永平寺町松岡下合月23-3
} 
球数から好中球数を予測することは危険であるこ とを報告した. ${ }^{2}$ がん化学療法による好中球減少 症のリスクファクターに関する検討は過去に数多 く実施されている。本稿では, 好中球減少症のリ スクファクターに関する過去の研究について系統 的に調査を行い，概略を紹介するとともに，これ らの研究で十分に検討されていなかった薬物相互 作用の問題, pharmacoethnicity の問題という新た な視点について, 我々の研究から得られた知見と 今後の展望について述べる.

\section{がん薬物療法による好中球減少症に 関する過去の知見}

がん薬物療法における既知の重篤な好中球減少 症，および発熱性好中球減少症のリスクファクター について，過去の研究によって得られた知見につ いて系統的にレビューするために, PubMed で網羅 的な文献検索を行い関連する研究報告を収集した。 検索語として, antineoplastic agents [Mesh terms], antineoplastic combined chemotherapy protocols [Mesh terms], neutropenia [Mesh terms], neutropenic, risk factors [Mesh terms], logistic, model, prediction, predictive を用いた。最終の文献検索は 2014 年 3 月に行った．アウトカムとして重篤な（grade 3/4 または grade 4）好中球減少症発現率，または発 熱性好中球減少症発現率を採用し，そのリスク ファクターについて検討が行われた研究を対象と した。総説, メ夕解析, 症例報告は対象から除外 した. PubMed 検索によりヒットした 976 文献に ついて論文のタイトルと要約を基にスクリーニン グを行った．スクリーニングによって選択された 論文について全文を精查し，また各文献の参考文 献から追加を行い, 最終的に 45 報が選択基準に 合致した (表 1). ${ }^{3-47}$ これらの研究は統計解析の 手法において, 単変量解析の結果のみを報告した ものと多変量解析の結果を報告したものに大別さ れた．約半数が後向き研究であり，カルテなどの 診療記録, 診療情報データベース, 臨床研究デー 夕の 2 次利用などが認められた。

がん化学療法による好中球減少症発現に影響を 与える要因は, 薬物・治療側の要因と, 患者側の
要因に大別できる.薬物側の要因として, 薬理作用, 投与量や投与方法, 薬物の物理化学的特性や薬物 動態学的特性などが考えられる。一方, 患者側の 要因として, 年齢, 性別, 全身状態 (performance status: PS), 栄養状態, 嗜好, 肝機能や腎機能, 合併症, 併用薬剤, 過去の治療歴, 薬物への感受 性, 遺伝的要因, 人種などが考えられている。例 えば，米国で乳がん，肺がん，大腸がんなどの患 者を対象に実施された患者登録から 3,760 名の デー夕を用い，化学療法後の好中球減少関連事象 (好中球減少症, 発熱性好中球減少症, 好中球減少 を伴う感染症）の発現リスクが検討されている. ${ }^{39}$ この研究では, 年齢とがん種による調整が行われた 結果, 過去の化学療法実施歴, レジメンや治療強度, 肝機能異常, 腎機能異常, 治療開始時の白血球数 低值などが重篤な好中球減少症のリスク因子として 挙げられている. また乳がん患者を対象とした複数 の研究において, 糖尿病や心血管系の合併症が重 篤な好中球減少症または発熱性好中球減少症のリ スクファクターとして挙げられている.

性別は複数の研究で重篤な好中球減少症のリス クファクターとして報告されており, 女性が男性 よりも高いリスクを有していることが示唆されて いる. ${ }^{3,4,16,21,25)}$ しかし, 性別が重篤な好中球減少症 の発現率に影響を与えることについて，その明確 な機序は明らかにされていない.アムルビシンの 投与患者を対象にリスクファクターを検討した Watanabe $ら^{3)}$ と Makihara $~^{4)}$ は，それぞれ女性 において重篤な好中球減少症のリスクが高いこと を報告しているが, その機序に対する考察は異なっ ている. Watanabeらは同じ研究において重篤な好 中球減少症のリスクファクターとして同定された ヘモグロビン濃度が女性において低值であること から，その関連性を考察しており， Makiharaらは アムルビシンの代謝過程における性差を可能性の ある機序として挙げている. 医薬品の副作用発現 率について性差を報告した研究があり, ${ }^{48,49)}$ また薬 物代謝酵素やトランスポーターの活性, 糸球体滤 過速度, さらに体脂肪率の差に起因した分布容積 の差などが性差の要因として考えられている. ${ }^{50)}$

全身状態を表す PS はドセタキセル投与患者を 対象とした Ozawa らの検討 ${ }^{17}$ で発熱性好中球減 


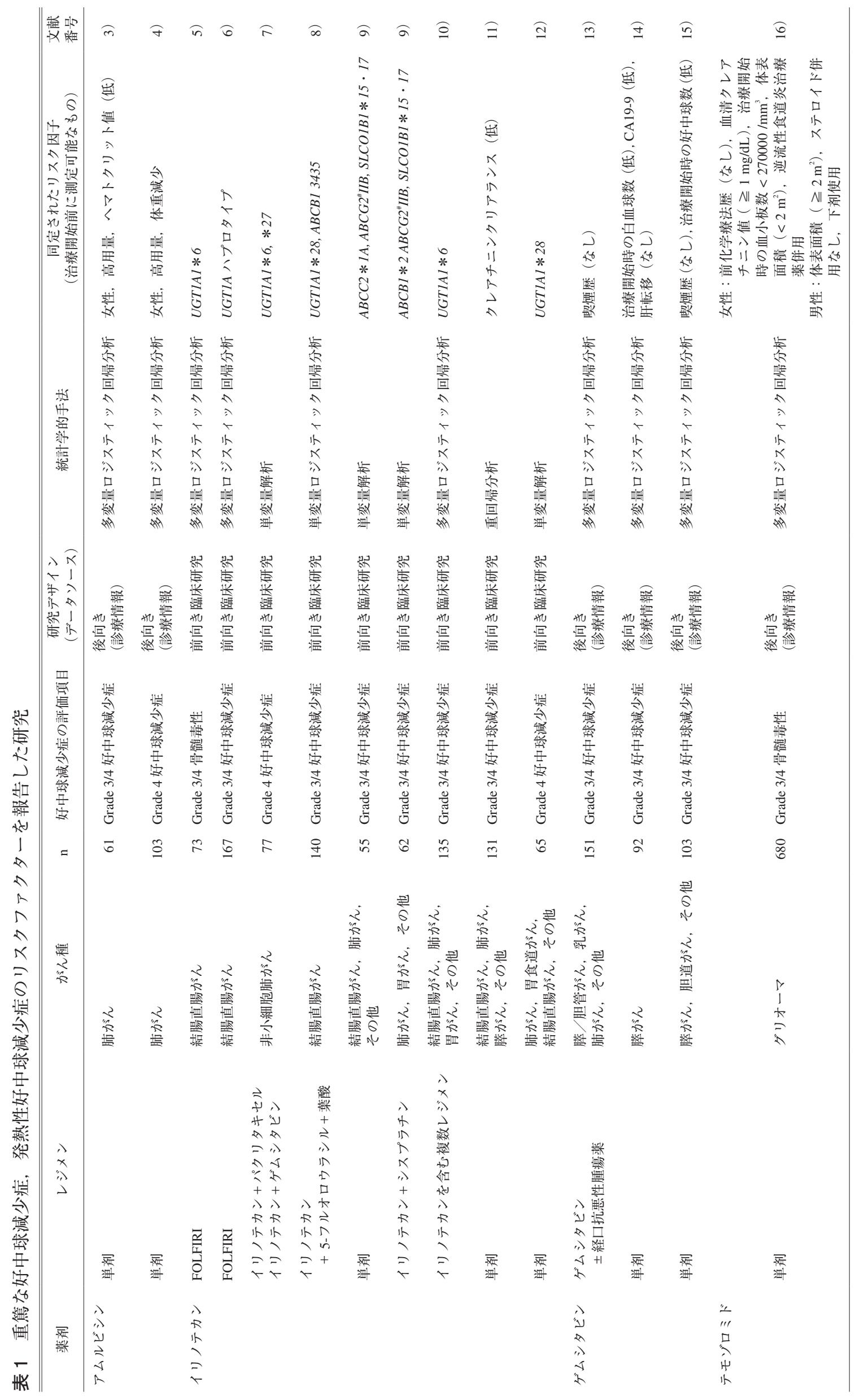




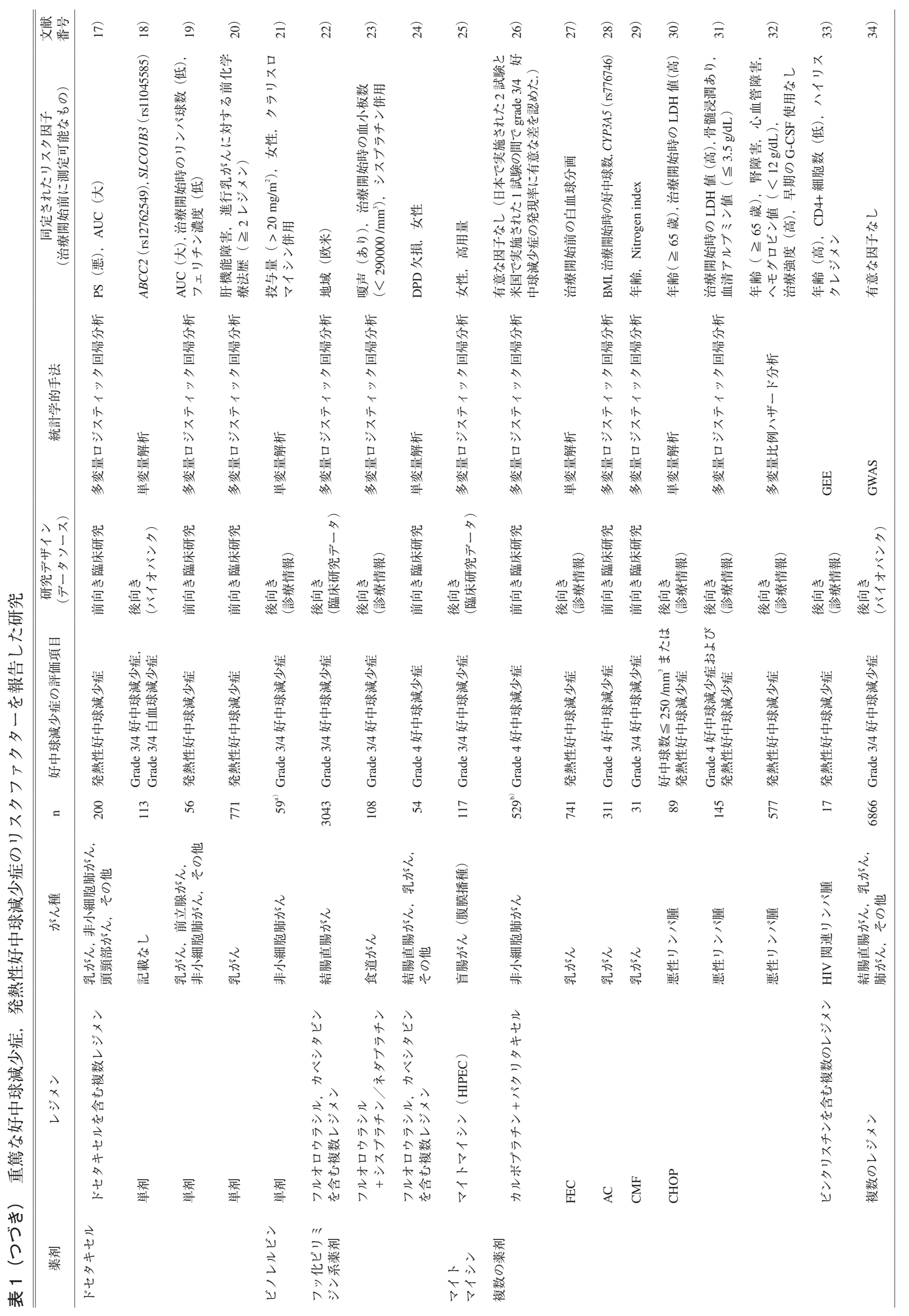




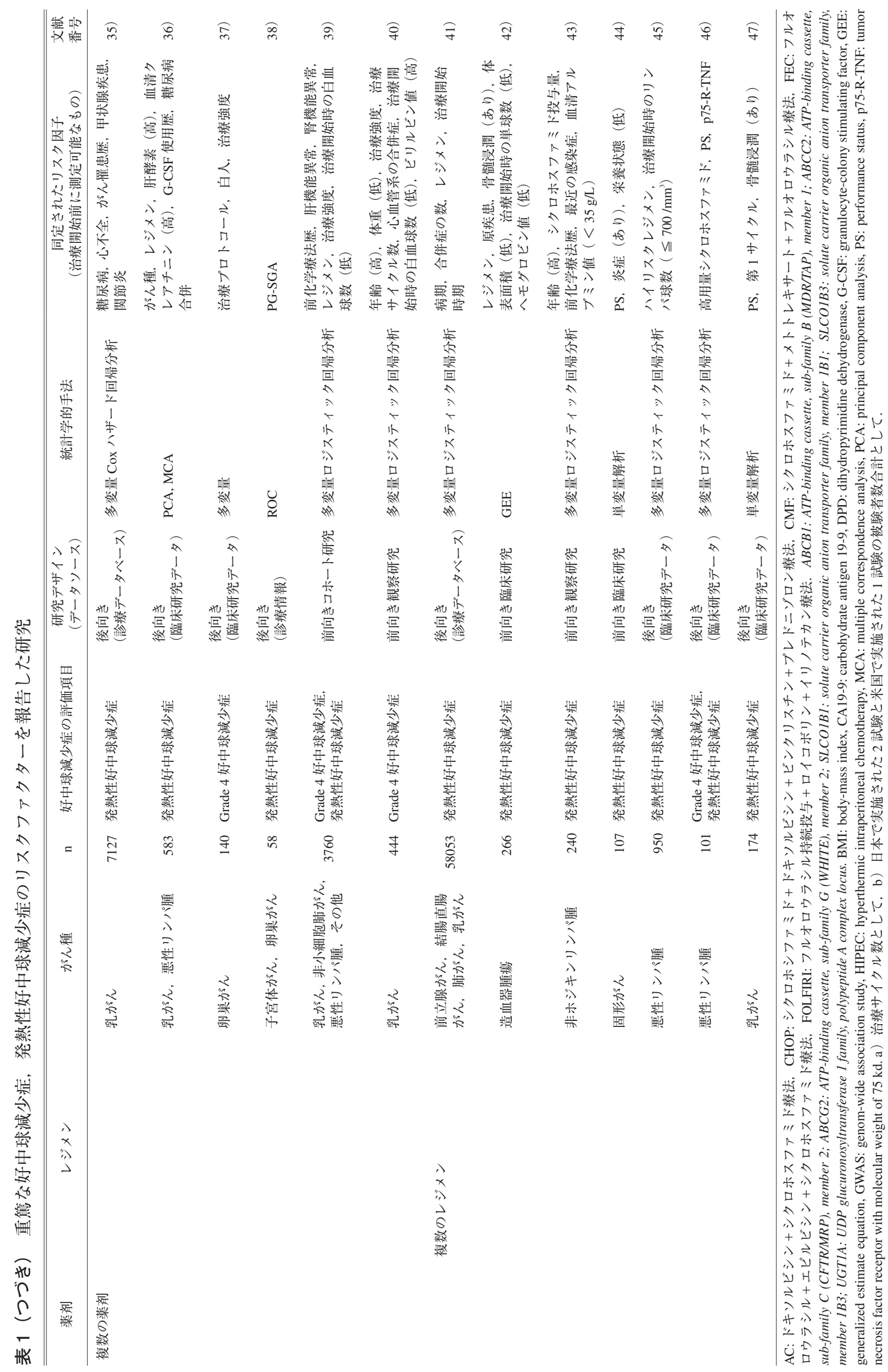


少症のリスクファクターとして, 悪性リンパ腫の 複数レジメンを対象としたVoog らの検討 ${ }^{46)}$ にお いて grade 4 好中球減少症および発熱性好中球減 少症のリスクファクターとして報告されている. そのほかに複数の研究においてPS は単変量解析 の結果ではあるが統計学的に有意な因子として挙 げられている. ${ }^{19,44,45,47)}$

治療開始前の臨床検査值は, 重篤な好中球減少 症または発熱性好中球減少症のリスクファクターと しての意義が数多く検討されている. 薬物の代謝 や排泄と関連する肝機能や腎機能関連の臨床検査 值, $\left.{ }^{11}, 16,20,32,34,39,40\right)$ 治療開始前の骨䯣機能や薬物の分布 容積と関連する血球算定検査值 3, 15, 16, 19, 27, 28, 32, 33, 39, 40, 42, 45 栄養状態や炎症関連の臨床検查值 ${ }^{17,29,31,38,43-45)}$ など がリスクファクターとして報告されている.

さらに, イリノテカン塩酸塩に扮ける $U D P$ glucuronosyltransferase（UGT) 1A1 のような薬物 代謝酵素の遺伝子多型，および幾つかの薬物トラ ンスポーターに関連した遺伝子多型が好中球減少 症のリスク因子として同定されている. ${ }^{5-111,13,18,24,28)}$ 重篤な好中球減少症あるいは発熱性好中球減少症 の発現と遺伝子多型の関連性が検討された研究の うち, Hazama ら ${ }^{5)}$ および Onoue $~^{{ }^{10)}}$ の報告のよ うに既知の重要なりスクファクターの影響につい て考慮され，調整済みオッズ比が報告されている 例もあるが，遺伝子多型の影響のみが単変量解析 で検討されている研究も多く, 結果を解釈する際 には交絡因子の影響に注意が必要である。

そのほかに少数ではあるが, 人種 ${ }^{35)}$, 地域差 ${ }^{22,26}$ を重篤な好中球減少症のリスクファクターとして 報告した研究が見受けられる。

\section{薬物相互作用による 好中球減少症リスクの増大}

がん患者の多くが様々な合併症を持ちながら薬 物療法を受けているなかで, 薬物相互作用はがん 治療に携わる薬剤師が適切に管理すべき重要な問 題である. Riechelmann らはがん患者における薬 物相互作用の危険性について報告している. ${ }^{51}$ 調 査対象となった外来通院患者 405 名のうち， $27 \%$ の患者で 276 件の薬物相互作用の可能性がある組
み合わせが処方されており，そのうちの 36 件は 抗悪性腫瘍薬と併用薬との薬物相互作用であっ た。 そして, 予測される薬物相互作用の影響に基 づき, major, moderate, minor の3 段階に分類し た結果, 臨床的に大きな影響が懸念される major と分類されるものは 25 件（9\%）に認められた こと, 半数以上が薬物動態学的相互作用であった ことが報告されている. 従って, 併用薬郕がコ ントロールされていない臨床デー夕を基にした研 究では, 重篤な好中球減少症や発熱性好中球減少 症の発現リスクに対する薬物相互作用の影響は無 視できない可能性があるが, 表 1 に示した研究 において併用薬剤の影響はほとんど検討されてい ないのが現状であった。

著者らはビンカアルカロイド系抗悪性腫瘍薬の ビノレルビンと抗菌薬のクラリスロマイシンを併 用すると，重篤な好中球減少症のリスクが 4.52

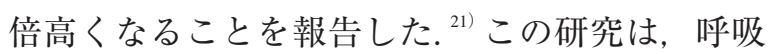
器内科病棟を担当していた薬郕師が, ビノレルビ ンによる重篤な骨髄抑制を経験し, 同じようにビ ノレルビンが投与されても大きな副作用が現れな かったほかの患者との相違点に興味を持ったこと が発端となった。カルテを詳細に調査した結果, 併用薬剤のなかにクラリスロマイシンが含まれる 患者において, 好中球減少症が重篤化している印 象を持った.

ビンカアルカロイド系の抗悪性腫瘍薬であるビ ノレルビンは，その投与によって用量依存的に好 中球減少をはじめとする骨髄抑制を起こすことが 知られており, 好中球減少症が本薬の用量規制因 子である. 非小細胞肺がん, 乳がんに効果が認め られているビノレルビンは, 国内で実施された非 小細胞肺がん患者を対象とした第正相臨床試験に おいて， 69.2\%の患者に grade 3 以上の重篤な好

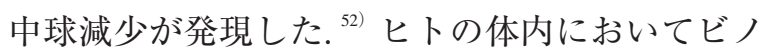
レルビンは肝薬物代謝酵素である cytochrome P450（CYP）3A で代謝され，体外に排泄される と考えられている. ${ }^{53,54)}$ またビノレルビンは $\mathrm{P}$ 糖 タンパク質によって細胞内から細胞外に輸送され る基質であることも明らかとなっている. ${ }^{55,56)}$

クラリスロマイシンは 14 員環骨格を持つマク ロライド系抗生物質であり, 呼吸器感染症など 
種々の感染症治療に用いられるほか, 本薬に見ら れる抗炎症作用を期待して, 慢性呼吸器疾患患者 等に対しても使用されることが多い薬剤である. ${ }^{57)}$ マクロライド系抗生物質は CYP3A と結合し, そ の活性を不可逆的に阻害すること, ${ }^{58}$ また, $\mathrm{P}$ 糖 タンパク質の阻害剤としても知られている. ${ }^{59,60)}$

文献を調査した結果, ビノレルビンとクラリス ロマイシンの薬物相互作用を直接報告した研究は なかった。そこで，より詳細な検討を行いビノレ ルビンとクラリスロマイシンの薬物相互作用の可 能性について, 薬物相互作用の有無だけでなく, オッズ比を算出し, 実際にどの程度のリスクの上 昇と臨床的な影響が予想されるのかを定量的に検 証を行う研究を計画した。

研究材料として, 福井大学医学部附属病院の病 院情報システムに蓄積された投薬, 臨床検査など の情報を用いた。 2003 年 5 月 30 日〜2008 年 1 月 31 日までの間, ビノレルビンの投与を受けた非 小細胞肺がん患者を対象とした. 28 日間を 1 コー スの治療期間と定義し，そのほかの影響因子とし て, 年齢や性別, 肝機能, 腎機能と関連する臨床 検査值等の患者背景因子, ビノレルビンの投与量, CYP3A 阻害薬の併用, ほかの抗悪性腫瘍薬の併 用, 過去の重篤な好中球減少症発現歴, 過去の抗 悪性腫瘍薬投与歴を調查した。これらの変動因子 に対する曝露の有無によってコホートを定義し，

Common Terminology Criteria for Adverse Events （CTCAE）ver3.0による grade 3 以上の重篤な好 中球減少症をアウトカムとして, その発現リスク をオッズ比として算出した，本研究では，がん化 学療法による好中球減少症について既知で重要な リスクファクターである PS に関する情報をカル テから正確に得ることができなかった. そのため, 多変量解析による調整は適切ではないと考えて実 施せず，単変量解析のみを実施した。

25 名の患者における 59 コースを解析対象とし た.クラリスロマイシンが併用された 19 コース では，12 コース（63.2\%）に扔いて grade 3 以上 の重篤な好中球減少症が認められたのに対して, クラリスロマイシンを併用しなかった 40 コース では 11 コース $(27.5 \%)$ において重篤な好中球 減少症が認められており（図1), クラリスロマ

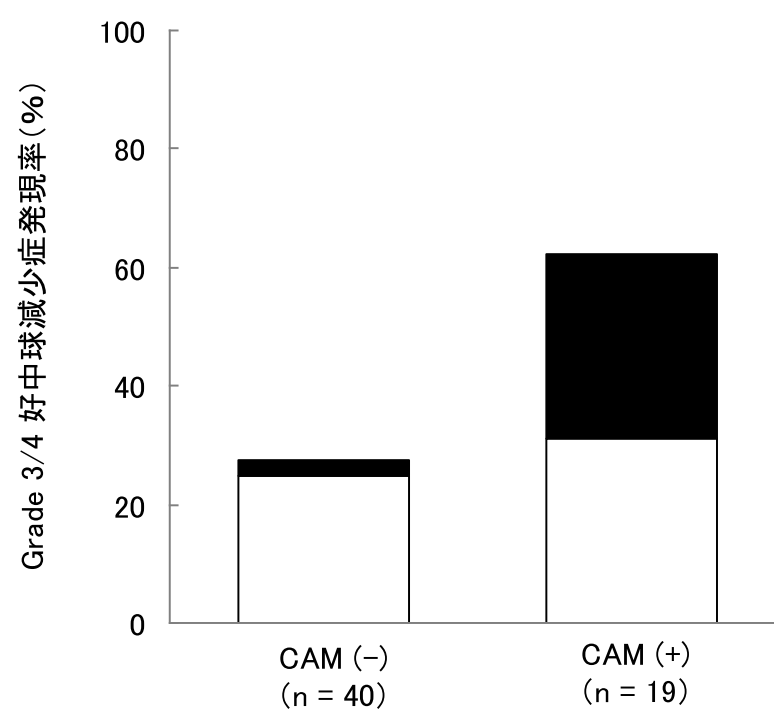

図1 クラリスロマイシンがビノレルビンによる重篤な 好中球減少症発現リスクに与える影響

$\square$ grade 3, $\square$ grade 4. CAM (-) : クラリスロマイシン併用 なし群, CAM $(+)$ ：クラリスロマイシン併用あり群。文献 21）より改変.

イシンの併用によって重篤な好中球減少症を発現 する割合が増加していた，特に，クラリスロマイ シン併用群では grade 4 の好中球減少発現率が非 併用群と比較して高くなっていた（31.6％vs $2.5 \% ; P=0.0033)$.

クラリスロマイシン併用群と非併用群の背景因 子を比較すると, クラリスロマイシン併用群では 年齢の中央值が統計学的に有意に高 $<（ P<0.05$, Mann-Whitney の $U$ 検定), また統計学的な有意 差はないものの女性の割合が高い傾向およびクレ アチニンクリアランスが低い傾向を示していた (表 2). 重篤な好中球減少症の発現に影響する因 子を探索する目的で単変量解析を行った結果, ビ ノレルビンの投与量, クラリスロマイシン併用の 有無, 女性について重篤な骨髄抑制の発現との関 連が示唆され，それぞれのオッズ比（95\%信頼 区間）は $0.07(0.01-0.59)$, $4.52 （ 1.41-14.45)$, 4.55（1.39-14.29）であった（表 3）.

以上の結果から, ビノレルビンとクラリスロマ イシンを併用することによって, 重篤な好中球減 少症のリスクが高まる可能性が示唆された。一方, クラリスロマイシン併用群で女性の割合が高い傾 向にあったこと, 高齢者が多かったことが結果に 
表 2 クラリスロマイシン併用の有無による背景因子の分布

\begin{tabular}{|c|c|c|c|}
\hline & $\begin{array}{c}\text { クラリスロマイシン } \\
\text { 併用あり } \\
(19 \text { コース })\end{array}$ & $\begin{array}{c}\text { クラリスロマイシン } \\
\text { 併用なし } \\
(40 \text { コース })\end{array}$ & \\
\hline 男性／女性（コース数） & $12 / 7$ & $30 / 10$ & $\mathrm{NS}^{\mathrm{b})}$ \\
\hline 年齢 $(\text { 歳 })^{a)}$ & $74(68-74)$ & $61(57-68)$ & $P=0.032^{\mathrm{c})}$ \\
\hline ビノレルビン投与量 $\left(\mathrm{mg} / \mathrm{m}^{2}\right)^{\mathrm{a})}$ & $23.8(22.7-24.8)$ & $22.6(20.4-24.2)$ & $\mathrm{NS}^{\mathrm{c})}$ \\
\hline 総ビリルビン $(\mathrm{mg} / \mathrm{dL})^{\mathrm{a})}$ & $0.6(0.4-0.7)$ & $0.5(0.4-0.675)$ & $\mathrm{NS}^{\mathrm{c})}$ \\
\hline AST (単位 /L) $)^{\mathrm{a})}$ & $24(21-28)$ & $20(16.25-26)$ & $\mathrm{NS}^{\mathrm{c})}$ \\
\hline クレアチニンクリアランス $(\mathrm{mL} / \mathrm{min})^{\mathrm{a})}$ & $58.7(52.4-74.0)$ & $87.3(46.6-97.9)$ & $\mathrm{NS}^{\mathrm{c})}$ \\
\hline 治療開始時の好中球数 $\left(\text { cells } / \mathrm{mm}^{3}\right)^{\mathrm{a})}$ & $3800(2464-4950)$ & $2963(2231-4961)$ & $\mathrm{NS}^{\mathrm{c})}$ \\
\hline 過去の化学療法歴あり（コース数） & 10 & 31 & $\mathrm{NS}^{\mathrm{b})}$ \\
\hline 過去の grade $3 / 4$ 好中球減少症発現歴あり（コース数） & 6 & 13 & $\mathrm{NS}^{\mathrm{b})}$ \\
\hline 他の抗がん剂併用あり（コース数） & 6 & 9 & $\mathrm{NS}^{\mathrm{b})}$ \\
\hline クラリスロマイシン以外の CYP3A4 阻害薬併用あり (コース数) & 4 & 7 & $\mathrm{NS}^{\mathrm{b})}$ \\
\hline
\end{tabular}

AST: aspartate aminotransferase, NS: not significant. a) 中央值（25th-75th パーセンタイル）, b） Fisher の正確確率検定, c） MannWhitney の $U$ 検定. 文献 21）より改変引用.

表 3 ビノレルビンによる重篤な好中球減少症のリスクファクター

\begin{tabular}{lccc}
\hline \hline & オッズ比 & $95 \%$ 信頼区間 & $P$ \\
\hline ビノレルビン投与量 $\left(<20 \mathrm{mg} / \mathrm{m}^{2}\right)$ & 0.07 & $0.01-0.59$ & 0.005 \\
クラリスロマイシン併用 & 4.52 & $1.41-14.45$ & 0.012 \\
その他のCYP3A 阻害薬 & 0.29 & $0.06-1.47$ & 0.174 \\
化学療法歴あり & 0.3 & $0.07-1.21$ & 0.126 \\
Grade 3 以上の好中球減少症歴あり & 1.24 & $0.37-4.18$ & 0.762 \\
年齢（>65 歳） & 1.36 & $0.47-3.96$ & 0.595 \\
女性 & 4.55 & $1.39-14.29$ & 0.017 \\
治療前の好中球数 & 1.88 & $0.64-5.51$ & 0.292 \\
AST & 0.38 & $0.04-3.61$ & 0.639 \\
総ビリルビン & 2.15 & $0.71-6.52$ & 0.265 \\
クレアチニンクリアランス & 0.71 & $0.22-2.52$ & 0.773 \\
\hline AST:
\end{tabular}

AST: aspartate aminotransferase. 文献 21）より改変引用

影響している可能性は否定できず，単変量解析の みを実施した本研究の限界であると考える.また, 同一患者であっても，治療コースごとに独立した サンプルとして解析を行っていることから，治療 回数を重ねた患者の存在がバイアスとなって結果 に影響を与えている眯念が残る。実際に，本研究 の解析対象のなかに，ビノレルビンを 10 コース 投与された女性が扔り，そのうち9コースで grade 3 の好中球減少症を認めていた。本患者に おいてクラリスロマイシンは 3 コースで併用され ており，いずれも grade 3 の好中球減少症を発現 していた。このように，本研究はサンプリングと 解析方法の点でバイアスや交絡の影響を完全には 否定できず，得られたオッズ比の解釈において注 意すべき点があると考えられる.

女性がビノレルビンによる重篤な好中球減少症 のリスクファクターとして抽出されている点につ
いて，先述のようにサンプリング方法に伴うバイ アス，あるいはクラリスロマイシン併用との交絡 といった可能性は否定できない。 そのほかに, 薬 物動態や造血細胞における感受性の男女差などが 可能性として挙げられるものの，それを裏付ける ようなデー夕は現時点で報告されておらず，詳細 は不明である。

ビノレルビンの投与量を減量せず, $20 \mathrm{mg} / \mathrm{m}^{2}$ 以上の投与量で用いることは重篤な好中球減少症 のリスクファクターの1つであると考えられた。 また，ビノレルビンの投与量が $20 \mathrm{mg} / \mathrm{m}^{2}$ 以上で あった 46 コースのうち, クラリスロマイシンは 15 コースで併用されており, そのうちの 12 コー ス $(80 \%)$ で重篤な好中球減少症が発現してい たが，クラリスロマイシンが併用されなかった 31 コースのうち重篤な好中球減少症が発症した のは 11 コース $(44.5 \%)$ であった。このことか 
らも, クラリスロマイシンの併用が重要なリスク ファクターであることが推察される. クラリスロ マイシンを投与中の患者においてビノレルビンの 投与が予定された場合，対応策としてクラリスロ マイシンの中止とビノレルビンの減量が考え得 る. ビノレルビンの投与量が $20 \mathrm{mg} / \mathrm{m}^{2}$ 未満に減 量されていた例では，クラリスロマイシン併用の 有無や性別にかかわらず重篤な好中球減少症が発 現していなかったことから，減量は重篤な好中球 減少症のリスク回避という点では有効かもしれな い. しかしながら, 減量による治療効果への影響 など不明確な点があり, 安易には推奨できない. 現時点ではクラリスロマイシンを中止することが 現実的な対応であると考える．著者の所属施設で は注射抗がん剤を投与予定の患者全員について， 薬剂師が治療前日にカルテの確認を行い, 臨床検 查值，併用薬剤，投与量や投与間隔などに問題が ないことを確認している. ビノレルビンの投与が 予定されている患者では, クラリスロマイシン併 用の有無を確認し，クラリスロマイシンを服用中 の患者においては処方医に処方提案を行うことに よって併用を回避することで重篤な好中球減少症 の発現を防止している．当院の場合，クラリスロ マイシンは抗菌薬としての投与目的よりも，慢性 気道炎症の改善など副次的な作用を目的に使用さ れていることが多い，重篤な好中球減少症による 化学療法の遅延や感染症のリスクを回避する重要 性について処方医に説明することによって，クラ リスロマイシン中止の提案に対しての受け入れは 良好である。

本研究のデザインとして, 我々は後向きコホー ト研究のデザインを用いた。この方法は，すでに 存在する母集団を対象に検討が行えること, 予測 因子の測定が完了しており，測定時にバイアスが 生じにくいこと，コントロール群との比較から オッズ比を算出することができることが利点であ る. 一方, 前向きの研究デザインと比較した場合 の弱点として, 重要な変動因子が測定されていな かったり，測定の質に問題があったりするなど予 測因子の内容や質のコントロールが不可能である 点が挙げられる。後向きコホート研究は, 結果の 解釈に際し上記の点を踏まえつつ慎重な判断が求
められるものの, 既存の診療情報を活用した薬物 療法のリスク評価方法として活用していくべきで あると考える。

\section{好中球減少症のリスクに対する 人種差の影響}

医薬品開発を効率化するため, 臨床試験デー夕 の国際的共有化, 国際共同臨床試験の増加が認め られる。がん薬物療法の領域においても欧米を中 心とした国際的な臨床試験グループによって実施 される大規模臨床試験の結果から，世界的な標準 治療の確立・普及が進められている。一方で, 人 種・遺伝学的, 社会・文化的背景の差異に起因す る薬物動態・薬力学的反応性の差異などが認識さ れるようになり, pharmacoethnicityという概念が 注目されるようになってきた. ${ }^{61}$

ドセタキセルは，我が国に導入された当初より， 海外の標準的な用量よりも少ない投与量が用いられ ている薬凨である.すなわち, 海外では $75 \mathrm{mg} / \mathrm{m}^{2}$, あるいは $100 \mathrm{mg} / \mathrm{m}^{2}$ の用量が広く用いられている のに対して, 国内では $60 \mathrm{mg} / \mathrm{m}^{2}, 70 \mathrm{mg} / \mathrm{m}^{2}$ が標 準的に使用されてきた。 2008 年に我が国でドセ 夕キセルの去勢抵抗性前立腺がんに対する適応が 追加された際, 国内でははじめて最高用量となる $75 \mathrm{mg} / \mathrm{m}^{2}$ の投与量が承認された。この適応追加 は主に国内で害施された第 II 相試験と海外で害施 された第正相試験のデータが根拠として用いられ ている. ${ }^{62,63)}$ 両試験の主な特徵を表 4 に示す。国 内で実施された第 II 相試験では, $70 \mathrm{mg} / \mathrm{m}^{2}$ の投 与量が採用されているのに対して, 海外の第吕相 試験では $75 \mathrm{mg} / \mathrm{m}^{2}$ が用いられている。両試験は ほぼ同じような適格基準で被験者の組み入れが実 施されているが，ドセタキセルの投与量以外に顆 粒球増殖因子（G-CSF）の予防的投与に関する 規定が異なっており，国内の第 II 相試験では発熱 性好中球減少症または grade 4 好中球減少症の発 現時の G-CSF 治療的投与，および前コースの副 作用発現状況に応じた G-CSF の予防的投与が認 められていたのに対し，海外第 III 相試験では発熱 性好中球減少症に対する治療的投与の从が認めら れていた。 また，減量規定について異なる部分が 
表 4 去勢抵抗性前立腺癌に対するドセタキセルの臨床試験の比較

\begin{tabular}{|c|c|c|c|c|c|c|}
\hline & 投与量 & 症例数 & $\begin{array}{c}\text { 年齢中央值 } \\
\text { (才) }\end{array}$ & $\begin{array}{c}\text { 顆粒球増殖因子の } \\
\text { 予防的投与 }\end{array}$ & $\begin{array}{l}\text { 重篤な好中球 } \\
\text { 減少症の発現率 }\end{array}$ & $\begin{array}{l}\text { 発熱性好中球 } \\
\text { 減少症の発現率 }\end{array}$ \\
\hline $\begin{array}{l}\text { 国内 phase II } \\
\text { ( Naito, 2008) }\end{array}$ & $70 \mathrm{mg} / \mathrm{m}^{2}$ & 43 & 65 & $\begin{array}{c}\text { 前コースの副作用に } \\
\text { 応じて認める }\end{array}$ & $93 \%$ & $16.3 \%$ \\
\hline $\begin{array}{l}\text { 海外 phase III } \\
\text { (Tannock, 2004) }\end{array}$ & $75 \mathrm{mg} / \mathrm{m}^{2}$ & 332 & 68 & 認めない & $32 \%$ & $3 \%$ \\
\hline
\end{tabular}

あり，国内第 II 相試験では好中球減少症に伴う減 量規定はなく，治験責任医師または治験分担医師 が必要と判断した場合に減量が可能であったのに 対し，海外第 III相試験では発熱性好中球減少症や 感染症の発現時，また治療開始時の好中球数に応 じたドセタキセルの減量規定が定められていた. タキソテール®注の前立腺がんに対する適応追加 を審査した医薬品医療機器総合機構の審査報告書 によると，国内第 II 相試験では $56.1 \%$ ，海外第 III 相試験では $12.9 \%$ でドセタキセルの減量が行われ ており，国内第 II 相試験における減量や投与中止 の主な原因は grade 3 以上の感染事象であったと 報告されている. ${ }^{64)}$ 最も注目すべきは両試験で報 告されている好中球減少症および発熱性好中球減 少症の発現頻度である。国内第 II 相試験では grade 3 以上の重篤な好中球減少症発現率が $93 \%$, 発熱性好中球減少症発現率は $16.3 \%$ あったのに 対し，海外第 III相試験ではそれぞれ，32\%，3\% と報告されており，国内第 II 相試験の高い発現率 が目立っている。海外第而相試験において生存期 間の有意な延長が証明されていることを根拠に， この試験で使用された $75 \mathrm{mg} / \mathrm{m}^{2}$ の投与量で承認 申請がなされ，適応が追加されたが，国内では同 用量を用いた臨床試験は実施されていない点に注 意が必要である。また，ドセタキセルの添付文書 （タキソテール ${ }^{\otimes}$ 点滴静注用 添付文書, 第 23 版, サノフィ(株), 2013 年 10 月改訂）には $60 \mathrm{mg} / \mathrm{m}^{2}$ と $70 \mathrm{mg} / \mathrm{m}^{2}$ の投与量における副作用発現率が比 較されており（表 5)，高用量の投与によって重 篤な副作用の発現率が高くなることが注意喚起さ れていることから， $75 \mathrm{mg} / \mathrm{m}^{2}$ でドセタキセルを 投与した際の安全性が懸念される。国内で実施さ れた第 I 相臨床試験において, 日本人におけるド セタキセルの最大耐量と推奨用量が示されてお り, 白血球減少, 好中球減少症が用量規制因子で
表 5 ドセタキセル投与量ごとの好中球減少症発現率

\begin{tabular}{|c|c|c|}
\hline & $60 \mathrm{mg} / \mathrm{m}^{2}$ & $70 \mathrm{mg} / \mathrm{m}^{2}$ \\
\hline 好中球減少（全体） & $95.2 \%$ & $98.4 \%$ \\
\hline 好中球減少（grade 3 以上） & $84.6 \%$ & $90.0 \%$ \\
\hline 好中球減少（grade 4） & $60.6 \%$ & $73.7 \%$ \\
\hline
\end{tabular}
2013 年 10 月改訂）より引用

あり, 最大耐量は 70 90 mg/m², 推奨用量は 60 $\mathrm{mg} / \mathrm{m}^{2}$ と報告されている. ${ }^{65)}$ また, これとは別に 卵巣がん患者を対象に, $70 \mathrm{mg} / \mathrm{m}^{2}$ の初回投与量 について日本人における安全性が確認されてい る. ${ }^{66)}$ 好中球減少症は適切な支持療法により管理 が可能な副作用であるため, 著者は十分な経験を 持つ医療チームが重篤な好中球減少症のリスクに ついて熟知したうえで高用量のドセタキセルを用 いることは可能であると考える，そのなかで薬郕 師が臨床試験から得られた知見を十分に活用し， 安全性の確保に役割を果たしていくことが必要で ある。

我々はドセタキセルの前立腺がんに対する適応 追加において投与量の設定に疑問を持ったことを きっかけに，海外で実施された臨床試験成績を日 本人へ外挿する際, あるいは逆に日本から世界に 向けてエビデンスを発信する際に, 薬剂の投与量 設定の相違が障壁となる可能性を感じた. そこで, ドセタキセルによる好中球減少症の発現を例とし て, 日本と海外における薬物の用量一反応性にお ける相違点を検証するための検討を計画した。そ のための手段として, 臨床試験の実施地域と重篤 な好中球減少症の発現率との関連性を多変量解析 の手法で検証した。 ${ }^{67}$

ドセタキセル単剤を治療群に含む臨床第 II 相, 第 III相試験の論文を網羅的に収集し, 論文に報告 されている患者背景因子や副作用発現率などの データを抽出した。これらのデータに臨床試験が 


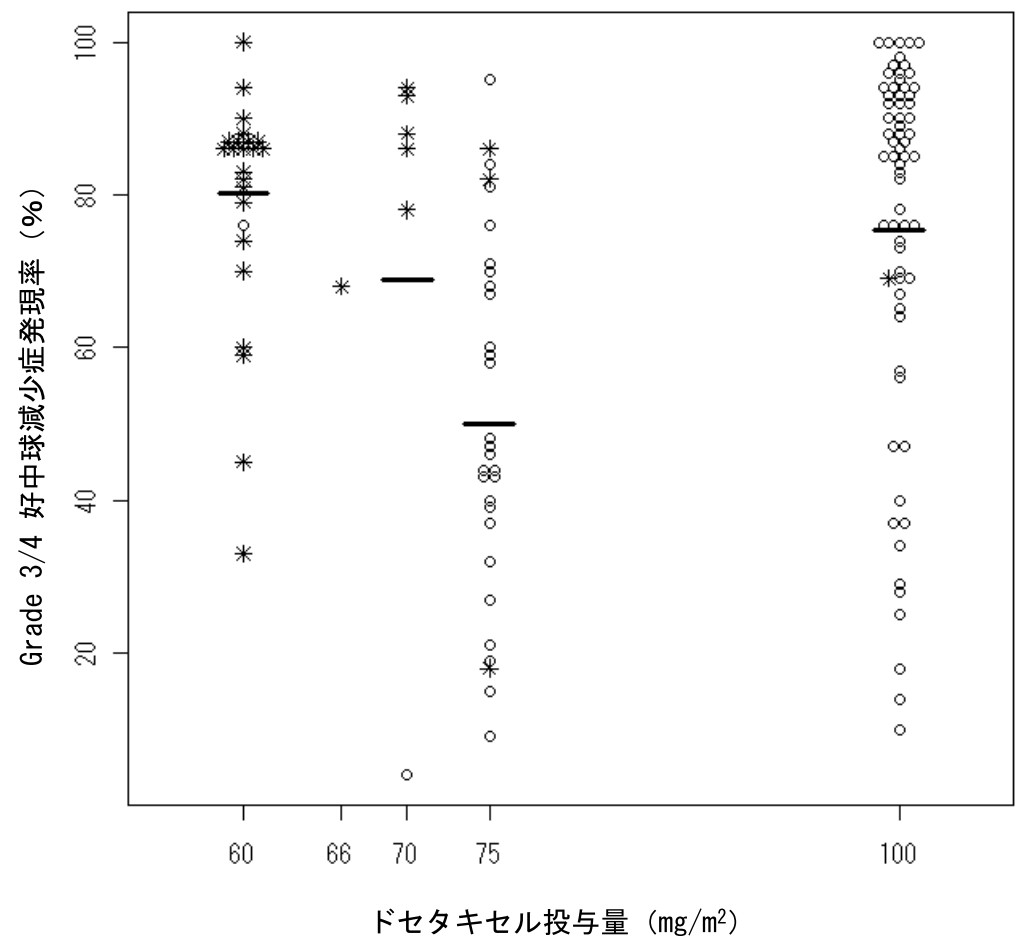

図 2 臨床試験実施地域別に見たドセタキセル投与量と重篤な好中球減 少症発現率の関係

一各投与量の被験者全体における重篤な好中球減少症の発現率，*アジアで実施さ れた臨床試験, ○アジア以外の地域を中心に実施された臨床試験. 文献 67)より改変.

表 6 ドセタキセルによる重篤な好中球減少症と関連するリスクファクター

\begin{tabular}{|c|c|c|c|c|c|c|}
\hline & \multicolumn{3}{|c|}{ 単変量解析 } & \multicolumn{3}{|c|}{ 多変量解析 } \\
\hline & オッズ比 & 95\%信頼区間 & $P$ & オッズ比 & 95\%信頼区間 & $P$ \\
\hline アジアで実施された試験 & 2.20 & $0.93-5.22$ & 0.073 & 19.0 & $3.64-99.0$ & 0.001 \\
\hline ドセタキセル投与量 & 1.01 & $0.99-1.03$ & 0.266 & 1.08 & $1.03-1.13$ & 0.001 \\
\hline $\mathrm{PS}>1$ & 0.99 & $0.96-1.01$ & 0.287 & 0.99 & $0.96-1.02$ & 0.444 \\
\hline 年齢（中央値） & 0.97 & $0.91-1.03$ & 0.300 & 1.02 & $0.94-1.10$ & 0.598 \\
\hline 被検者における女性の割合 & 1.01 & $1.00-1.02$ & 0.082 & & 解析から除外 a) & \\
\hline 化学療法歴 (2nd ライン以降) & 0.50 & $0.24-1.02$ & 0.057 & & 解析から除外 a) & \\
\hline
\end{tabular}

PS: Performance status. PS > 1: PS > 1 以上の被験者の割合. a) ステップワイズ法を用いた多変量ロジスティック回帰分析により。 統計学的に有意でないため最終モデルから除外. 文献 66）より改変引用.

主に実施された地域（アジア vs それ以外の地域） の情報を加え，重篤な好中球減少症の発現率と関 連する因子を多変量解析により探索した。

その結果，アジアで実施されたドセタキセルの 臨床試験では，欧米を中心に実施された臨床試験 と比較して，低用量のドセタキセルが用いられて いるにもかかわらず，重篤な好中球減少症の発現 頻度が高かった（図 2)。臨床試験の実施地域お よびドセタキセルの投与量が重篤な好中球減少症 の発症率と関連する独立した因子として抽出さ れ，アジアで実施された臨床試験はそれ以外の地
域で実施された臨床試験と比較して 19 倍高いリ スクを有していた（表 6).

この結果から，アジア人に対するドセタキセル の安全な投与量が欧米を中心としたほかの地域の 人々とは異なることが示唆された，従って，海外 で実施された臨床試験の結果を根拠に, 我が国で 高用量 $\left(75 \mathrm{mg} / \mathrm{m}^{2}\right)$ のドセタキセル投与が承認さ れたことを手放しに喜ぶことはできない.

母集団薬物動態解析の結果から日本人と欧米人 ではドセタキセルの血中濃度レベルにおける薬物 動態に大きな差はないと報告されている. ${ }^{68)}$ 一方, 
日米で実施された非小細胞肺がんにおけるパクリ タキセル + カルボプラチン療法の Common-Arm Analysis では, トランスポーター発現レベルの差 などが臨床成績, 副作用発現率の日米間相違に関 与していることが示唆されている. ${ }^{26)}$ 好中球減少 は骨髄における造血細胞の抗がん剂曝露量に依存 すると考えられる. 薬物の骨髄への移行や造血細 胞への取り込み・排出過程において, 種々のトラ ンスポーターが重要な役割を果たしていると推測 される. ${ }^{69,70)}$ トランスポーターの発現量や活性の 個体差は, 造血細胞への抗がん剂曝露に影響する 可能性がある。このような問題の解決にはトラン スポーターの遺伝子多型情報を活用した投与量設 定の個別化などさらなる研究の推進が必要である と考えられる。

ドセタキセルの投与量と重篤な好中球減少症の 関連性について, 本研究で得られた結果はオッズ 比が $1.08 （ 95 \%$ 信頼区間 : $1.03-1.13, P=0.001$ ) と統計学的に有意ではあるものの，一見するとリ スクファクターとして臨床における重要性は高く ない印象を持つ結果が得られた。しかし本研究で はドセタキセルの投与量を連続変数として取り 扱ったため，オッズ比が 1.08 であることは投与 量が $1 \mathrm{mg} / \mathrm{m}^{2}$ 増加するごとに重篤な好中球減少症 のリスクが 1.08 倍増加することを意味している. これは投与量が $10 \mathrm{mg} / \mathrm{m}^{2}$ 増加すると重篤な好中 球減少症のリスクが約 2 倍になることを示してい る。個別の試験では, Harveyらの報告でドセ夕 キセル $60 \mathrm{mg} / \mathrm{m}^{2}, 75 \mathrm{mg} / \mathrm{m}^{2}, 100 \mathrm{mg} / \mathrm{m}^{2}$ の用量に 対し, それぞれの grade 3/4 好中球減少症発現率 は 76.4\%， 83.7\%，93.4\%と報告されており，用 量依存性が認められている例や, ${ }^{71}$ 表 3 に示した 我が国のデー夕を考慮しても，ドセタキセルの投 与量と重篤な好中球減少症の発現率に関連がある ことは明らかであり, 高用量のドセタキセルを用 いる場合には重篤な好中球減少症に対して十分な 備えが必要であると考える。

本研究の限界として, 論文発表されたデー夕を 解析に使用していることによって生じる問題点が 挙げられる。すなわち，個々の患者の情報が失わ れている可能性や試験ごとの変動因子の測定方 法, 時期などに起因する誤差を考慮していないこ
と等である。また, 論文化されていない臨床試験 が解析には含まれておらず, 公表バイアスが存在 する可能性も考えられる.

去勢抵抗性前立腺がんに対するレジメンに限ら ず，アジア人においては，ドセタキセルによる重 篤な好中球減少症の発現リスクが高いことを考慮 し，海外のエビデンスを導入する際に，ドセタキ セルの用量設定については慎重な判断が必要であ る. 本研究の結果も踏まえ, 当院では去勢抵抗性 前立腺がんに対するドセタキセル＋プレドニゾ ロン療法のレジメンは $70 \mathrm{mg} / \mathrm{m}^{2}$ を標準的なドセ タキセルの投与量として登録されている。がん化 学療法を安全に実施するために, レジメン登録の 制度が一般的になり，施設内におけるレジメンの 審査に薬剤師が積極的に関与するようになってい る.このような場で本研究の知見を活かし, 安全 で有効ながん化学療法を提供できるように議論す るなど，役割を果たしていくことが薬剤師に求め られていると考える. さらに, 当院では新薬の採 用前に, 薬剂部による製薬メーカーへのヒアリン グが必ず実施されるが，開発段階で日本人の症例 数が限られている薬剤については, 用量設定の根 拠や日本人, アジア人の被験者における治療効果, 副作用の発現状況等について活発な質疑が行われ ている. 本研究の成果は, 当院において薬剤師が 国際共同開発における問題点について意識を高 め, 医薬品の有効性と安全性を確保するために積 極的に行動する背景となっている.

\section{おわりに}

ビノレルビンとクラリスロマイシンの薬物相互 作用に関する薬剤疫学研究では, 薬物相互作用に よる副作用のリスク上昇を定量的に明らかにし， 薬学的マネジメントを行ううえで有用な情報を提 供した。ドセタキセルの好中球減少症リスクにお ける ethnicity の影響に関する検討では, 海外のエ ビデンスを日本人に適応する際, ethnicityの違い による反応性の差を考慮すべきであることを示 し, 臨床における安全な治療法選択に寄与した。 またこのような ethnicity による影響の存在が治 療開発の戦略を検討するうえでも重要であること 
を示した

これらの研究は, がん薬物療法による重篤な好 中球減少症のリスクファクターについて, 新たな 知見を追加した。加えて，薬物療法に関するリス クファクターを評価する目的で薬片師が行う研究 の手法として, 薬剂疫学的手法の有用性を示すこ とができた点でも意義があるものである.

薬物相互作用や ethnicity による影響の問題は, がん薬物療法による好中球減少症のリスクファク ターを研究する際, 常に考慮すべき重要な問題で あると考えられたが，過去の研究においては十分 な検討が行われてこなかった，今後，がん薬物療 法による好中球減少症に限らず，医薬品による副 作用のリスクファクターを研究する際には, 研究 者が併用薬剤の情報や研究対象の人種等について 考慮し，そのリスクについて検討されるよう期待 したい.

\section{謝辞}

本研究の遂行にあたり終始ご指導賜りました, 政田幹夫教授，中村敏明講師をはじめ，福井大学 医学部附属病院薬剤部の皆様, 名城大学薬学部 後藤伸之教授をはじめとする共同研究者の皆様方 に心より御礼を申し上げます。

\section{引用文献}

1) Bodey GP, Buckley M, Sathe YS, Freireich EJ, Quantitative relationships between circulating leukocytes and infection in patients with acute leukemia, Ann Intern Med, 1966, 64, 328-340.

2）根來 寛, 矢野良一, 谷 大輔, 渡辺享平, 塚本 仁, 五十嵐敏明, 中村敏明, 脇屋義文, 後藤伸之, 横山照由, 政田幹夫, 固形がん患者における抗が ん剤の適正使用のための白血球数評価, 医療薬 学, 2008, 34, 320-327.

3) Watanabe H, Ikesue H, Oshiro M, Nagata K, Mishima K, Takada A, Suetsugu K, Sueyasu M, Egashira N, Harada T, Takayama K, Nakanishi Y, Oishi R, Risk factors for predicting severe neutropenia induced by amrubicin in patients with advanced lung cancer, Chemotherapy, 2012, 58, 419-425.
4) Makihara RA, Makino Y, Yamamoto N, Yokote N, Nokihara H, Sekine I, Ohe Y, Tamura T, Yamamoto $\mathrm{H}$, Gender difference in hematological toxicity among lung cancer patients receiving amrubicin monotherapy, Jpn J Clin Oncol, 2012, 42, 1187-1191.

5) Hazama S, Mishima H, Tsunedomi R, Okuyama Y, Kato T, Takahashi K, Nozawa H, Ando H, Kobayashi M, Takemoto H, Nagata N, Kanekiyo S, Inoue Y, Hamamoto Y, Fujita Y, Hinoda Y, Okayama N, Oba K, Sakamoto J, Oka M, UGT1A1*6, 1A7*3, and $1 \mathrm{~A} 9 * 22$ genotypes predict severe neutropenia in FOLFIRI-treated metastatic colorectal cancer in two prospective studies in Japan, Cancer Sci, 2013, 104, 1662-1669.

6) Lévesque E, Bélanger AS, Harvey M, Couture F, Jonker D, Innocenti F, Cecchin E, Toffoli G, Guillemette C, Refining the UGT1A haplotype associated with irinotecan-induced hematological toxicity in metastatic colorectal cancer patients treated with 5-fluorouracil/irinotecan-based regimens, J Pharmacol Exp Ther, 2013, 345, 95-101.

7) Nakamura Y, Soda H, Oka M, Kinoshita A, Fukuda M, Fukuda M, Takatani H, Nagashima S, Soejima Y, Kasai T, Nakatomi K, Masuda N, Tsukamoto K, Kohno S, Randomized phase II trial of irinotecan with paclitaxel or gemcitabine for non-small cell lung cancer: association of UGT1A $1 * 6$ and UGT1A1 * 27 with severe neutropenia, $J$ Thorac Oncol, 2011, 6, 121-127.

8) Glimelius B, Garmo H, Berglund A, Fredriksson LA, Berglund M, Kohnke H, Byström P, Sørbye H, Wadelius M, Prediction of irinotecan and 5-fluorouracil toxicity and response in patients with advanced colorectal cancer, Pharmacogenomics $J$, 2011, 11, 61-71.

9) Sai K, Saito Y, Maekawa K, Kim SR, Kaniwa N, Nishimaki-Mogami T, Sawada J, Shirao K, Hamaguchi T, Yamamoto N, Kunitoh H, Ohe Y, Yamada Y, Tamura T, Yoshida T, Matsumura Y, Ohtsu A, Saijo N, Minami H, Additive effects of drug transporter genetic polymorphisms on irinotecan pharmacokinetics/pharmacodynamics in Japanese cancer patients, Cancer Chemother Pharmacol, 2010, 66, 95-105.

10) Onoue M, Terada T, Kobayashi M, Katsura T, Matsumoto S, Yanagihara K, Nishimura T, Kanai M, Teramukai S, Shimizu A, Fukushima M, Inui K, 
UGT1A $1 * 6$ polymorphism is most predictive of severe neutropenia induced by irinotecan in Japanese cancer patients, Int J Clin Oncol, 2009, 14, 136-142.

11) de Jong FA, van der Bol JM, Mathijssen RH, van Gelder T, Wiemer EA, Sparreboom A, Verweij J, Renal function as a predictor of irinotecan-induced neutropenia, Clin Pharmacol Ther, 2008, 84, 254 262.

12) Innocenti F, Undevia SD, Iyer L, Chen PX, Das S, Kocherginsky M, Karrison T, Janisch L, Ramírez J, Rudin CM, Vokes EE, Ratain MJ, Genetic variants in the UDP-glucuronosyltransferase 1A1 gene predict the risk of severe neutropenia of irinotecan, J Clin Oncol, 2004, 22, 1382-1388.

13) O’Malley M, Healy P, Daignault S, Ramnath N, Cigarette smoking and gemcitabine-induced neutropenia in advanced solid tumors, Oncology, 2013, 85, 216-222.

14) Yoneyama K, Katsumoto E, Kurihara T, Kogo M, Ikegami A, Imawari M, Shimada K, Yoshikumi H, Inoue K, Kiuchi Y, Factors predicting the appearance of neutropenia in patients with advanced pancreatic cancer undergoing gemcitabine therapy, Hepatogastroenterology, 2012, 59, 894-898.

15) Kanai M, Morita $S$, Matsumoto $S$, Nishimura $T$, Hatano E, Yazumi S, Sasaki T, Yasuda H, Kitano T, Misawa A, Ishiguro H, Yanagihara K, Ikai I, Doi R, Fukushima M, A history of smoking is inversely correlated with the incidence of gemcitabine-induced neutropenia, Ann Oncol, 2009, 20, 1397-1401.

16) Armstrong TS, Cao Y, Scheurer ME, Vera-Bolaños E, Manning R, Okcu MF, Bondy M, Zhou R, Gilbert MR, Risk analysis of severe myelotoxicity with temozolomide: the effects of clinical and genetic factors, Neuro Oncol, 2009, 11, 825-832.

17) Ozawa $\mathrm{K}$, Minami $\mathrm{H}$, Sato $\mathrm{H}$, Logistic regression analysis for febrile neutropenia (FN) induced by docetaxel in Japanese cancer patients, Cancer Chemother Pharmacol, 2008, 62, 551-557.

18) Kiyotani K, Mushiroda T, Kubo M, Zembutsu H, Sugiyama Y, Nakamura Y, Association of genetic polymorphisms in SLCO1B3 and ABCC2 with docetaxel-induced leukopenia, Cancer Sci, 2008, 99, 967-972.

19) Alexandre J, Rey E, Girre V, Grabar S, Tran A, Montheil V, Rabillon F, Dieras V, Jullien V, Hérait P,
Pons G, Treluyer JM, Goldwasser F, Relationship between cytochrome $3 \mathrm{~A}$ activity, inflammatory status and the risk of docetaxel-induced febrile neutropenia: a prospective study, Ann Oncol, 2007, 18, 168-172.

20) Alexandre J, Bleuzen P, Bonneterre J, Sutherland W, Misset JL, Guastalla J, Viens P, Faivre S, Chahine A, Spielman M, Bensmaïne A, Marty M, Mahjoubi M, Cvitkovic E, Factors predicting for efficacy and safety of docetaxel in a compassionate-use cohort of 825 heavily pretreated advanced breast cancer patients, J Clin Oncol, 2000, 8, 562-573.

21) Yano R, Tani D, Watanabe $K$, Tsukamoto $H$, Igarashi T, Nakamura T, Masada M, Evaluation of potential interaction between vinorelbine and clarithromycin, Ann Pharmacother, 2009, 43, 453-458.

22) Haller DG, Cassidy J, Clarke SJ, Cunningham D, Van Cutsem E, Hoff PM, Rothenberg ML, Saltz LB, Schmoll HJ, Allegra C, Bertino JR, Douillard JY, Gustavsson BG, Milano G, O'Connell M, Rustum Y, Tabernero J, Gilberg F, Sirzén F, Twelves C, Potential regional differences for the tolerability profiles of fluoropyrimidines, J Clin Oncol, 2008, 26, 21182123.

23) Kogo M, Watahiki M, Sunaga T, Kaneko K, Yoneyama K, Imawari M, Kiuchi Y, Analysis of the risk factors for myelosuppression after chemoradiotherapy involving 5-fluorouracil and platinum for patients with esophageal cancer, Hepatogastroenterology, 2011, 58, 802-808.

24) Van Kuilenburg AB, Meinsma R, Zoetekouw L, Van Gennip AH, Increased risk of grade IV neutropenia after administration of 5-fluorouracil due to a dihydropyrimidine dehydrogenase deficiency: high prevalence of the IVS14+1g>a mutation, Int J Cancer, 2002, 101, 253-258.

25) Lambert LA, Armstrong TS, Lee JJ, Liu S, Katz MH, Eng C, Wolff RA, Tortorice ML, Tansey P, Gonzalez-Moreno S, Lambert DH, Mansfield PF, Incidence, risk factors, and impact of severe neutropenia after hyperthermic intraperitoneal mitomycin C, Ann Surg Oncol, 2009, 16, 2181-2187.

26) Gandara DR, Kawaguchi T, Crowley J, Moon J, Furuse K, Kawahara M, Teramukai S, Ohe Y, Kubota K, Williamson SK, Gautschi O, Lenz HJ, McLeod HL, Lara PN Jr, Coltman CA Jr, Fukuoka M, Saijo N, Fukushima M, Mack PC, Japanese-US common- 
arm analysis of paclitaxel plus carboplatin in advanced non-small-cell lung cancer: a model for assessing population-related pharmacogenomics, J Clin Oncol, 2009, 27, 3540-3546.

27) Jenkins P, Freeman S, Pretreatment haematological laboratory values predict for excessive myelosuppression in patients receiving adjuvant FEC chemotherapy for breast cancer, Ann Oncol, 2009, 20, 3440.

28) Tang NL, Liao CD, Wang X, Mo FK, Chan VT, Ng R, Pang E, Suen JJ, Woo J, Yeo W, Role of pharmacogenetics on adjuvant chemotherapy-induced neutropenia in Chinese breast cancer patients, J Cancer Res Clin Oncol, 2013, 139, 419-427.

29) Aslani A, Smith RC, Allen BJ, Pavlakis N, Levi JA, The predictive value of body protein for chemotherapy-induced toxicity, Cancer, 2000, 88, 796-803.

30) Rabinowitz AP, Weiner NJ, Tronic BS, Fridman M, Liberman RF, Delgado DJ, Severe neutropenia in CHOP occurs most frequently in cycle 1: a predictive model, Leuk Lymphoma, 2006, 47, 853-858.

31) Intragumtornchai $T$, Sutheesophon J, Sutcharitchan P, Swasdikul D, A predictive model for life-threatening neutropenia and febrile neutropenia after the first course of CHOP chemotherapy in patients with aggressive non-Hodgkin's lymphoma, Leuk Lympho$m a$, 2000, 37, 351-360.

32) Lyman GH1, Morrison VA, Dale DC, Crawford J, Delgado DJ, Fridman M; OPPS Working Group; ANC Study Group, Risk of febrile neutropenia among patients with intermediate-grade nonHodgkin's lymphoma receiving CHOP chemotherapy, Leuk Lymphoma, 2003, 44, 2069-2076.

33) Park J, Kim TM, Hwang JH, Kim NH, Choe PG, Song KH, Kim ES, Park SW, Kim HB, Kim NJ, Park WB, Oh MD, Risk factors for febrile neutropenia during chemotherapy for HIV-related lymphoma, J Korean Med Sci, 2012, 27, 1468-1471.

34) Low SK, Chung S, Takahashi A, Zembutsu H, Mushiroda T, Kubo M, Nakamura Y, Genome-wide association study of chemotherapeutic agent-induced severe neutropenia/leucopenia for patients in Biobank Japan, Cancer Sci, 2013, 104, 1074-1082.

35) Chia VM, Page JH, Rodriguez R, Yang SJ, Huynh J, Chao C, Chronic comorbid conditions associated with risk of febrile neutropenia in breast cancer patients treated with chemotherapy, Breast Cancer Res
Treat, 2013, 138, 621-631.

36) Chen C, Chan A, Yap K, Visualizing clinical predictors of febrile neutropenia in Asian cancer patients receiving myelosuppressive chemotherapy, J Oncol Pharm Pract, 2013, 19, 111-120.

37) Laskey RA, Poniewierski MS, Lopez MA, Hanna RK, Secord AA, Gehrig PA, Lyman GH, Havrilesky LJ, Predictors of severe and febrile neutropenia during primary chemotherapy for ovarian cancer, Gynecol Oncol, 2012, 125, 625-630.

38) Phippen NT, Lowery WJ, Barnett JC, Hall LA, Landt C, Leath CA 3rd, Evaluation of the PatientGenerated Subjective Global Assessment (PG-SGA) as a predictor of febrile neutropenia in gynecologic cancer patients receiving combination chemotherapy: a pilot study, Gynecol Oncol, 2011, 123, 360364.

39) Lyman GH, Kuderer NM, Crawford J, Wolff DA, Culakova E, Poniewierski MS, Dale DC, Predicting individual risk of neutropenic complications in patients receiving cancer chemotherapy, Cancer, 2011, 117, 1917-1927.

40) Schwenkglenks M, Pettengell R, Jackisch C, Paridaens R, Constenla M, Bosly A, Szucs TD, Leonard R, Risk factors for chemotherapy-induced neutropenia occurrence in breast cancer patients: data from the INC-EU Prospective Observational European Neutropenia Study, Support Care Cancer, 2011, 19, 483-490.

41) Hosmer W, Malin J, Wong M, Development and validation of a prediction model for the risk of developing febrile neutropenia in the first cycle of chemotherapy among elderly patients with breast, lung, colorectal, and prostate cancer, Support Care Cancer, 201, 19, 333-341.

42) Moreau M, Klastersky J, Schwarzbold A, Muanza F, Georgala A, Aoun M, Loizidou A, Barette M, Costantini S, Delmelle M, Dubreucq L, Vekemans M, Ferrant A, Bron D, Paesmans M, A general chemotherapy myelotoxicity score to predict febrile neutropenia in hematological malignancies, Ann Oncol, 2009, 20, 513-519.

43) Pettengell R, Bosly A, Szucs TD, Jackisch C, Leonard R, Paridaens R, Constenla M, Schwenkglenks M; Impact of Neutropenia in Chemotherapy-European Study Group (INC-EU), Multivariate analysis of febrile neutropenia occurrence in patients with non- 
Hodgkin lymphoma: data from the INC-EU Prospective Observational European Neutropenia Study, Br J Haematol, 2009, 144, 677-685.

44) Alexandre J, Gross-Goupil M, Falissard B, Nguyen ML, Gornet JM, Misset JL, Goldwasser F, Evaluation of the nutritional and inflammatory status in cancer patients for the risk assessment of severe haematological toxicity following chemotherapy, Ann Oncol, 2003, 14, 36-41.

45) Ray-Coquard I, Borg C, Bachelot T, Sebban C, Philip I, Clapisson G, Le Cesne A, Biron P, Chauvin F, Blay JY; ELYPSE study group, Baseline and early lymphopenia predict for the risk of febrile neutropenia after chemotherapy, Br J Cancer, 2003, 88, 181186.

46) Voog E, Bienvenu J, Warzocha K, Moullet I, Dumontet C, Thieblemont C, Monneret G, Gutowski MC, Coiffier B, Salles G, Factors that predict chemotherapy-induced myelosuppression in lymphoma patients: role of the tumor necrosis factor ligand-receptor system, J Clin Oncol, 2000, 18, 325-331.

47) Rahman Z, Esparza-Guerra L, Yap HY, Fraschini G, Bodey G, Hortobagyi G, Chemotherapy-induced neutropenia and fever in patients with metastatic breast carcinoma receiving salvage chemotherapy, Cancer, 1997, 79, 1150-1157.

48) Pirmohamed M, James S, Meakin S, Green C, Scott AK, Walley TJ, Farrar K, Park BK, Breckenridge $\mathrm{AM}$, Adverse drug reactions as cause of admission to hospital: prospective analysis of 18820 patients, BMJ, 2004, 329, 15-19.

49) Patel H, Bell D, Molokhia M, Srishanmuganathan J, Patel M, Car J, Majeed A, Trends in hospital admissions for adverse drug reactions in England: analysis of national hospital episode statistics 1998-2005, BMC Clin Pharmacol, 2007, 17 (doi:10.1186/14726904-7-9).

50) Anderson GD, Gender differences in pharmacological response, Int Rev Neurobiol, 2008, 83, 1-10.

51) Riechelmann RP, Tannock IF, Wang L, Saad ED, Taback NA, Krzyzanowska MK, Potential drug interactions and duplicate prescriptions among cancer patients, J Natl Cancer Inst, 2007, 99, 592-600.

52) Kudoh S, Takeda K, Nakagawa K, Takada M, Katakami N, Matsui K, Shinkai T, Sawa T, Goto I, Semba H, Seto T, Ando M, Satoh T, Yoshimura N, Negoro S, Fukuoka M, Phase III study of docetaxel compared with vinorelbine in elderly patients with advanced non-small-lung cell cancer: Results of the West Japan Thoracic Oncology Group Trial (WJTOG 9904), J Clin Oncol, 2006, 24, 3657-3663.

53) Kajita J, Kuwabara T, Kobayashi H, Kobayashi S, CYP3A4 is mainly responsible for the metabolism of a new vinca alkaloid, vinorelbine, in human liver microsomes, Drug Metab Disp, 2000, 28, 1121-1127.

54) Beulz-Riche D, Grude P, Sautel F, Filaquier C, Riche C, Ratanasavanh D, Characterization of human cytochrome P450 isoenzymes involved in the metabolism of vinorelbine, Fundam Clin Pharmacol, 2005, 19, 545-553.

55) Wong M, Balleine RL, Blair EY, McLachlan AJ, Ackland SP, Garg MB, Evans S, Farlow D, Collins M, Rivory LP, Hoskins JM, Mann GJ, Clarke CL, Gurney H, Predictors of vinorelbine pharmacokinetics and pharmacodynamics in patients with cancer, J Clin Oncol, 2006, 24, 2448-2455.

56) Adams DJ, Knick VC, P-glycoprotein mediated resistance to 5'-non-anhydro-vinblastine (Navelbine), Invest New Drug, 1995, 13, 13-21.

57) Gotfried MH, Macrolides for the treatment of chronic sinusitis, asthma, and COPD, Chest, 2004, 125, 52S-61S.

58) Larrey D, Tinel M, Pessayre D, Formation of inactive cytochrome P-450 Fe (II)-metabolite complexes with several erythromycin derivatives but not with josamycin and midecamycin in rats, Biochem Pharmacol, 1983, 32, 1487-1493.

59) Wang L, Kitaichi K, Hui CS, Takagi K, Takagi K, Sakai M, Yokogawa K, Miyamoto KI, Hasegawa T, Reversal of anticancer drug resisitance by macrolide antibiotics in vitro and in vivo, Clin Exp Pharmacol Physiol, 2000, 27, 587-593.

60) Wakasugi H, Yano I, Ito T, Hashida T, Futami T, Nohara R, Sasayama S, Inui K, Effect of clarithromycin on renal excretion of digoxin: Interaction with P-glycoprotein, Clin Pharmacol Ther, 1998, 64, 123-128.

61) O'Donnell PH, Dolan ME, Cancer pharmacoethnicity: ethnic differences in susceptibility to the effects of chemotherapy, Clin Cancer Res, 2009, 15, 48064814.

62) Naito S, Tsukamoto T, Koga H, Harabayashi T, Sumiyoshi Y, Hoshi S, Akaza H, Docetaxel plus prednisolone for the treatment of metastatic hor- 
mone-refractory prostate cancer: a multicenter phase II trial in Japan, Jpn J Clin Oncol, 2008, 38, 365372.

63) Tannock IF, de Wit R, Berry WR, Horti J, Pluzanska A, Chi KN, Oudard S, Théodore C, James ND, Turesson I, Rosenthal MA, Eisenberger MA, TAX 327 Investigators, Docetaxel plus prednisone or mitoxantrone plus prednisone for advanced prostate cancer, N Engl J Med, 2004, 351, 1502-1512.

64）“タキソテール注 審査報告書”, 独立行政法人 医薬品医療機器総合機構, 平成20年 7 月23日, pp15-18.

65）田口鐵男, 古江 尚, 仁井谷久暢, 石谷邦彦, 金丸 龍之介, 長谷川浩一, 有吉 寛, 野田起一郎, 古瀬 清行, 福岡正博, 薬師寺道明, 樫村 正, 新規抗癌 剂RP56976（Docetaxel）の第 I 相臨床試験, が んと化学療法, 1994, 21, 1997-2005.

66) Fujiwara K, Kohno I, Tanaka K, Ogita S, Sasaki Y, Hirabayashi K, Yakushiji M, Tsunematsu R, Terashima Y, Taguchi T, Ohashi Y, Noda K, Phase II dose escalation: a novel approach to balancing efficacy and toxicity of anticancer agents. Japanese Docetaxel Ovarian Cancer Study Group, Anticancer
Res, 1999, 19, 639-644.

67) Yano R, Konno A, Watanabe K, Tsukamoto H, Kayano Y, Ohnaka H, Goto N, Nakamura T, Masada $\mathrm{M}$, Pharmacoethnicity of docetaxel-induced severe neutropenia: integrated analysis of published phase II and III trials, Int J Clin Oncol, 2013, 18, 96-104.

68) Tanigawara Y, Sasaki Y, Otsu T, Fujii H, Kashimura M, Sasaki T, Okumura K, Taguchi T, Population pharmacokinetics of docetaxel in Japanese patients, Proc Am Soc Clin Oncol, 1996, 15, 479.

69) Chaudhary PM, Roninson IB, Expression and activity of P-glycoprotein, a multidrug efflux pump, in human hematopoietic stem cells, Cell, 1991, 66, 8594.

70) Guo CB, Li YC, Jin XQ, Chemoprotection effect of retroviral vector encoding multidrug resistance 1 gene to allow intensified chemotherapy in vivo, Cancer Chemother Pharmacol, 2006, 58, 40-49.

71) Harvey V, Mouridsen H, Semiglazov V, Jakobsen E, Voznyi E, Robinson BA, Groult V, Murawsky M, Cold S, Phase III trial comparing three doses of docetaxel for second-line treatment of advanced breast cancer, J Clin Oncol, 2006, 24, 4963-4970. 